\title{
Begonia jinyunensis (Begoniaceae, section Platycentrum), a new palmately compound leaved species from Chongqing, China
}

\author{
Bo Ding ${ }^{1 \dagger}$, Koh Nakamura $^{2^{*}}$, Yoshiko Kono ${ }^{2}$, Meng-Jung $\mathrm{Ho}^{2}$ and Ching-l Peng ${ }^{2^{*}}$
}

\begin{abstract}
Background: Continental China is the center of Begonia species diversity in Asia and contains more than 60 species out of about 110 named species of section Platycentrum. Mt. Jinyun, located in Chongqing City at the upper reaches of the Yangtze River, harbors a subtropical broadleaved forest with high species diversity. During a botanical survey in Mt. Jinyun, an unknown Begonia species of sect. Platycentrum with palmately compound leaves was collected and studied based on detailed morphological observations and cytological and molecular phylogenetic analyses.

Results: The unknown Begonia bears a superficial resemblance to B. hemsleyana in having palmately compound leaves, a feature unseen in other species of sect. Platycentrum in China. It is however sharply distinct from the latter in the acaulous habit with aerial stems seen only at anthesis and long rhizomes (vs. erect stems to $70 \mathrm{~cm}$ or taller with short rhizomes), 4-6 pinnatilobed leaflets with indistinct, decurrent petiolules (vs. 7-10 serrate leaflets with distinct petiolules), and white (vs. pink) tepals. Molecular phylogenetic analyses based on nuclear ribosomal DNA and chloroplast DNA sequences indicated that this species was allied to Platycentrum species occurring in Southwest and South-central China and Vietnam, including B. hemsleyana, and clearly separable from these species. Somatic chromosome number of $2 n=22$ was reported for this unknown species. The diploid chromosome number is agreeable with those published for Begonia sect. Platycentrum.
\end{abstract}

Conclusions: The unknown Begonia is confirmed to be a new species of sect. Platycentrum and hereto described as Begonia jinyunensis C.-I Peng, B. Ding \& Q. Wang.

Keywords: Begonia jinyunensis; Begonia hemsleyana; Begoniaceae; Chromosome number; Flora of China; ITS; Limestone; New species; rpl16; Sect. Platycentrum

\section{Background}

The mega-diverse genus Begonia L. (Begoniaceae) comprises ca. 1,500-1,600 species widely distributed in the tropical and subtropical regions of the world except Australia (Kiew 2005, Tebbitt 2005, Chung et al. 2014). Section Platycentrum (Klotzsch) A. DC. comprises about 110 species of herbs and subshrubs that are widely distributed in Asia, ranging from India to the Himalayas, Indo-China, China, Taiwan, and Malesia (Doorenbos et al. 1998, Shui et al. 2002). Continental China is the

\footnotetext{
* Correspondence: kohnakamur@gmail.com; bopeng@sinica.edu.tw ${ }^{\dagger}$ Equal contributors

${ }^{2}$ Herbarium (HAST), Biodiversity Research Center, Academia Sinica, Taipei 11542, Taiwan

Full list of author information is available at the end of the article
}

center of Begonia species diversity in Asia and contains more than 60 Platycentrum species predominantly in South of Yangtze River (Shui et al. 2002, Gu 2007, Wei et al. 2007). They are either terrestrial on thick humus, epiphytic on trees, or epipetric on rock faces or crevices at 100-2,200 m altitude (Shui et al. 2002). Many Begonia species are local- or site-endemics and even after the publication of Flora of China (Gu et al. 2007) many new Begonia species have been discovered (Liu et al. 2007, Shui 2007, Wei et al. 2007, Ku et al. 2008, Li et al. 2008, Peng et al. 2008a, 2008b, 2010, 2012, 2013, 2014), suggesting that the species-rich genus has not been fully explored in China.

Mt. Jinyun ( $29^{\circ} 49^{\prime} \mathrm{N}, 106^{\circ} 20^{\prime} \mathrm{E}$; Figure 1$)$ is located at the upper reaches of the Yangtze River and has the highest 


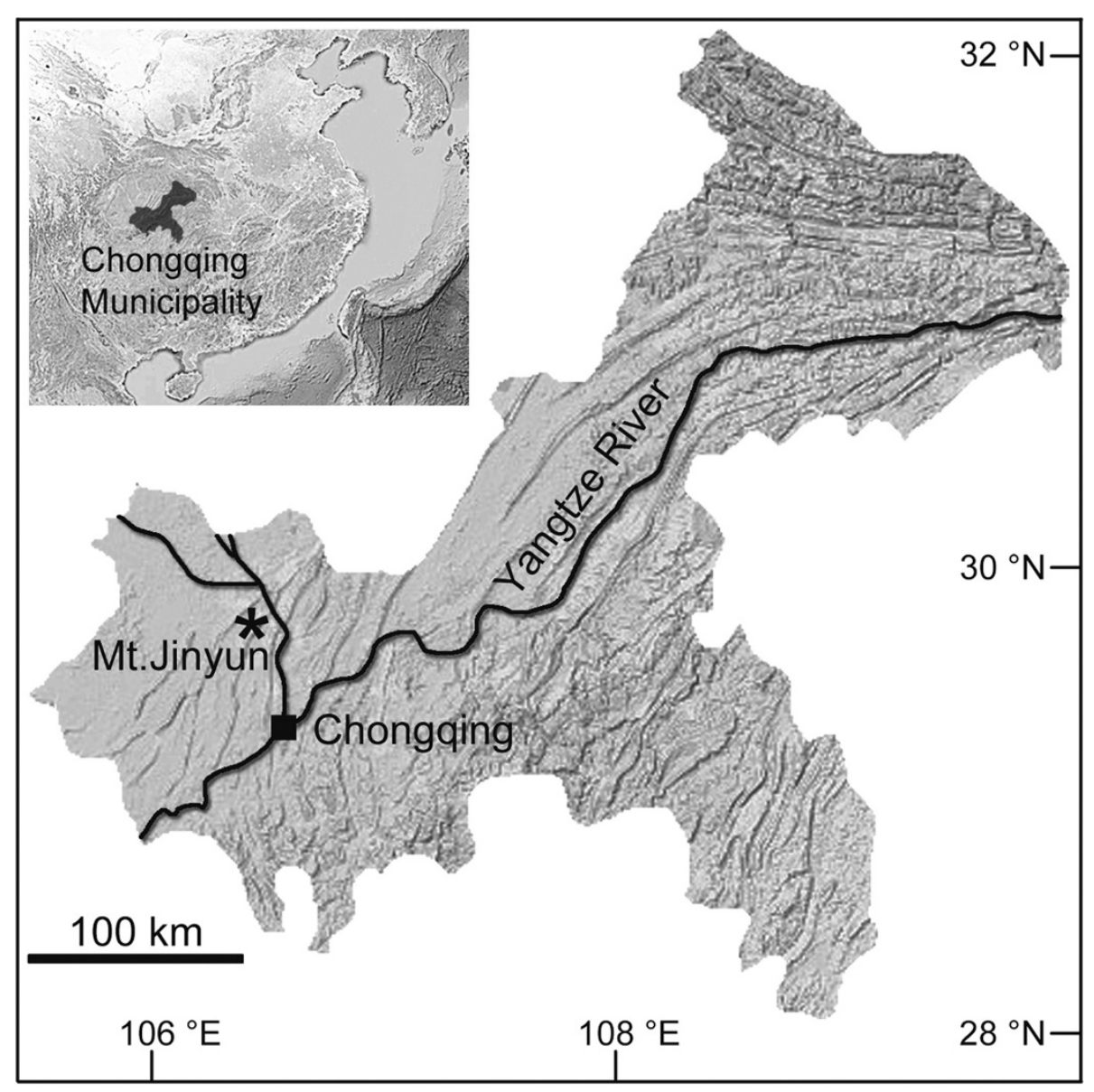

Figure 1 Distribution of Begonia jinyunensis (Mt. Jinyun of Chongqing Municipality, Southwest China).

peak $(950 \mathrm{~m})$ in Chongqing Municipality, Southwest China. The climate is subtropical monsoon, with annual mean temperature of $18.3^{\circ} \mathrm{C}$ and annual rainfall of $1,105 \mathrm{~mm}$, and the vegetation is mixed evergreen broadleaved and conifer forest, with patches of bamboos (Qing et al. 2004). The area, although only $20 \mathrm{~km}$ away from the center of the megacity, harbors a typical forest landscape of the Yangtze River basin and high species diversity, and is protected as Jinyun Mountain National Nature Reserve with the core area of 1,235 hectares (Qing et al. 2004). In a botanical survey of the nature reserve in July 2013, Bo Ding, Qian Wang, and Hai-Jun Wen collected an unknown Begonia of sect. Platycentrum with palmately compound leaves and sent it to Ching-I Peng for cultivation at the experimental greenhouse in Academia Sinica for careful examination. In Begonia sect. Platycentrum, only one species, B. hemsleyana Hook. f. occurring in Southern China (Southwest Guangxi and Southeast Yunnan) and northern Vietnam (Gu et al. 2007), has palmately compound leaves. Based on detailed morphological study, both of herbarium materials and living collection, and cytological and molecular phylogenetic analyses, we confirmed that the unknown Begonia is a new species, which is hereby described as Begonia jinyunensis C.-I Peng, B. Ding \& Q. Wang.

\section{Methods}

\section{Morphological study}

Living collections of Begonia jinyunensis (Bo Ding 20130701, Ching-I Peng 24108, 24109, 24110) were used for morphological observations. In addition, herbarium specimens representative of $B$. jinyunensis were carefully studied in IBSC.

\section{Molecular phylogenetic analyses}

Molecular phylogenetic analyses of B. jinyunensis incorporated $B$. hemsleyana and 21 species (Appendix 1); these 21 species fell in the same clade with $B$. hemsleyana in a previous phylogenetic study on Asian Begonia based on concatenated sequences of the internal transcribed spacer (ITS) region (including ITS1 and ITS2 and the 5.8S rRNA gene) of 18S-26S nuclear ribosomal DNA (nrDNA) and an intron of rpl16 gene (rpl16) of chloroplast DNA (cpDNA) (Chung et al. 2014). These species were mostly 
sect. Platycentrum (14 species including B. hemsleyana) but also included five species of sect. Diploclinium (Lind.) A. DC., two of sect. Sphenanthera (Hassk.) Warb., and B. longicarpa K. Y. Guan \& D. K. Tian, currently not assigned to any section (Chung et al., 2014). Note that Asian sections of Begonia are largely non-monophyletic (Thomas et al. 2011, Chung et al. 2014). Outgroup taxa were B. parvula H. Lév. \& Vaniot of sect. Reichenheimea (Klotzsch) A. DC. and B. ravenii C.-I Peng \& Y. K. Chen of sect. Diploclinium, which were placed outside of the clade (Chung et al. 2014). For B. jinyunensis three plants (Ching-I Peng 24108, 24109, 24110) from three localities in Mt. Jinyun were examined; for B. hemsleyana four plants, three from Yunnan (Ching-I Peng 17590, 20933, 22778) and one from Vietnam (Ching-I Peng 20204), were studied. For the other species one sample each was used. Samples sequenced in this study are indicated with asterisks (Appendix 1) and sequences of the other samples were cited from Chung et al. (2014). Methods of DNA extraction, PCR, and DNA sequencing followed Nakamura et al. (2012). DNA sequences were aligned using ClustalX ver. 1.8 (Thompson et al. 1997) and then manually adjusted. Phylogenetic analyses were based on a Bayesian approach using MrBayes ver. 3.1.2 (Ronquist \& Huelsenbeck 2003) and a maximum parsimony (MP) criterion using PAUP* ver. 4.0b10 (Swofford 2002).

In the Bayesian phylogenetic analysis, the best substitution models for the ITS and rpl16 data were selected as SYM + I and GTR + I, respectively, using KAKUSAN4 (Tanabe 2011) based on Bayesian information criterion (BIC). Two separate runs of Metropolis coupled Markov chain Monte Carlo analyses were performed, each with a random starting tree and four chains (one cold and three heated). The chain length was ten million generations, and the chain was sampled every one thousandth generation from the cold chain. The mixing and convergence of the chains of the two runs was assessed using Tracer ver. 1.5.0 (Drummond \& Rambaut 2007). The first 10\% of the total 10,000 sample trees were discarded as burn-in. After the burn-in, the effective sample sizes of all parameters were $>200$, indicating that the analyses sampled the posterior distributions of each parameter satisfactorily, and the values of Average Standard Deviation of Split Frequency (ASDSF) were below 0.005 . The $50 \%$ majority rule consensus tree of all the post-burn-in trees with Bayesian posterior probabilities $(P P)$ was visualized with FigTree ver. 1.3.1 (Drummond \& Rambaut 2007).

In the MP phylogenetic analysis, indels were treated as missing data. The characters were treated as unordered, and the character transformations were equally weighted. The branch collapse option was set to collapse at a minimum length of zero. A heuristic parsimony search was performed with 1,000 replicates of random additions of sequences with ACCTRAN character optimization, tree bisection-reconnection (TBR) branch swapping, and MULTREES and STEEPEST DESCENT options on. Statistical support for each clade was assessed by bootstrap analysis (Felsenstein 1985). Ten thousand replicates of heuristic searches, with the TBR branch swapping switched on and MULTREES options off, were performed to calculate bootstrap percentages $(B P)$.

\section{Chromosome cytology}

Somatic chromosome morphology was studied for one plant of B. jinyunensis (Ching-I Peng 24110, HAST) using root tips. The methods of pretreatment, fixation, and staining for chromosome observations followed our previous paper (Peng et al. 2012). Classification of the chromosome complements based on centromere position at mitotic metaphase followed Levan et al. (1964).

\section{Results and discussion}

\section{Molecular phylogeny based on nrDNA and cpDNA}

The aligned length of the ITS and rpl16 sequences was $695 \mathrm{bp}$ and 1,002 bp, respectively. In the concatenated data set, 323 nucleotide substitutions were found in 277 variable sites and 120 sites were parsimony informative among them. The Bayesian 50\% majority rule consensus tree with mean branch length and $P P$ is depicted (Figure 2). The MP analysis yielded 44 equally parsimonious trees of 641 steps with a consistency index $(\mathrm{CI})=0.682$, a retention index $(\mathrm{RI})=0.614$, and a rescaled consistency index $(\mathrm{RC})=0.418$. Clades supported with $B P \geq 50 \%$ in the MP strict consensus tree (not shown) were all recognized in the Bayesian tree. $B P$ was plotted on the Bayesian tree. Only clades supported by $P P \geq 0.95$ and/or $B P \geq 70 \%$ were considered adequately supported. Begonia jinyunensis resided in a clade with B. hemsleyana, B. augustinei, B. dryadis, B. edulis, and B. pedatifida $(P P=0.95 / B P<50 \%)$. These are species of sect. Platycentrum in Southwest and South-central China and Vietnam (Gu et al. 2007). Although phylogenetic relationship among the species within this clade was not fully resolved except for the clade of $B$. augustinei and $B$. dryadis $(0.97 /<50 \%)$, the six species were clearly separated from each other, and B. jinyunensis (1.0/100\%) and $B$. hemsleyana (1.0/99\%) were reciprocally monophyletic.

\section{Chromosomal features}

Somatic chromosomes at metaphase of $B$. jinyunensis were determined to be $2 n=22$ (Figure 3 ). The 22 chromosomes gradually varied in length from ca. 1.0 to $1.8 \mu \mathrm{m}$. Several larger chromosomes had centromeres at median or submedian positions but centromere position of smaller chromosomes could not be determined. No satellite was observed. For B. hemsleyana, somatic chromosome number $2 n=22$ was reported for plants from Yunnan, China (Tian et al. 2002. Note that the number was mistyped as $2 n=20$ in the abstract and thereby erroneously cited in 


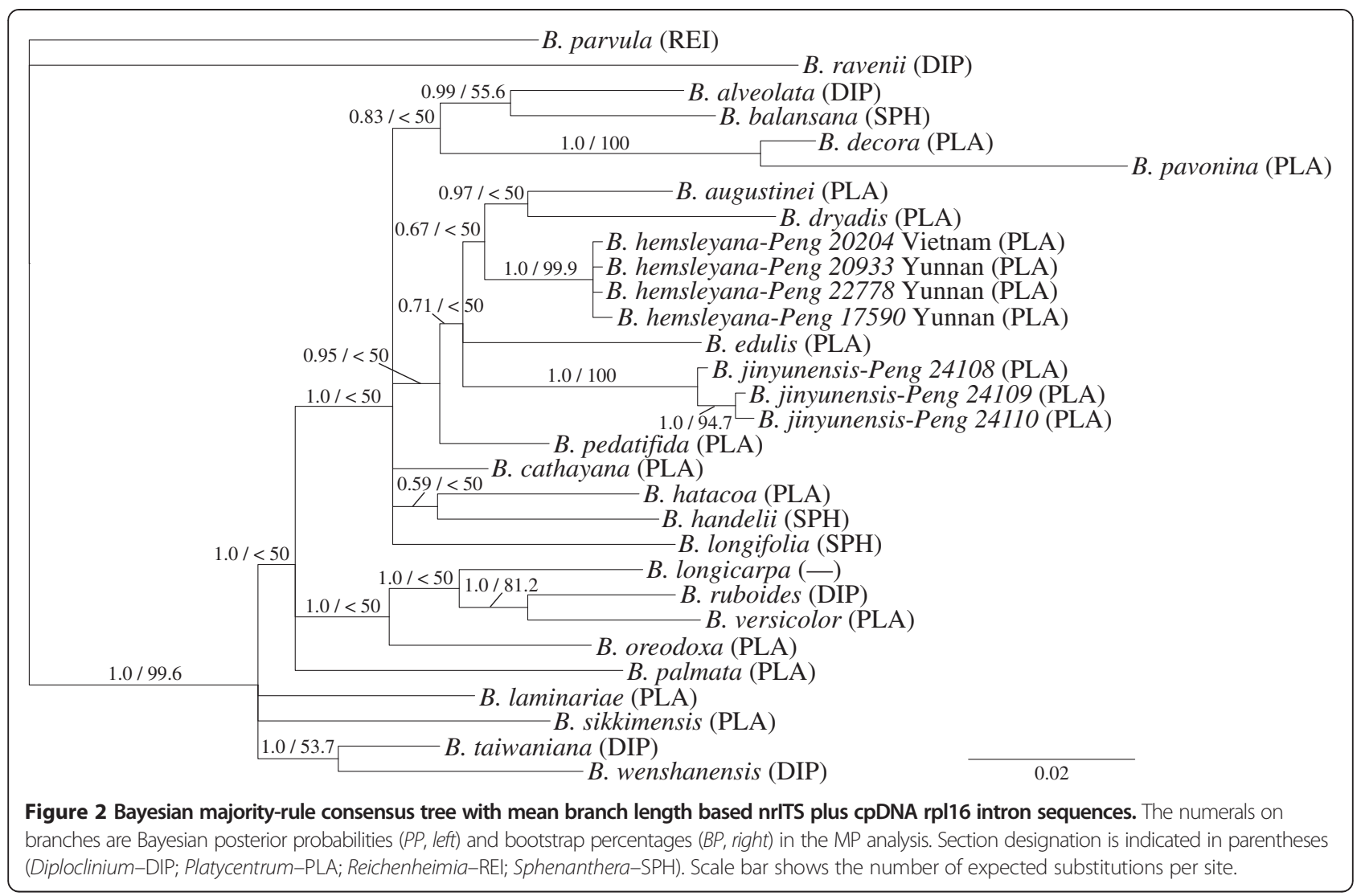

Index to Plant Chromosome Numbers [http://www.tropicos. org/Project/IPCN]; Nakata et al. 2003). Begonia jinyunensis and $B$. hemsleyana were karyologically indistinguishable due to the small chromosome size.

\section{Taxonomic treatment}

\section{Begonia jinyunensis}

C.-I Peng, B. Ding \& Q. Wang, sp. nov. (sect. Platycentrum) (Figures 4 and 5).

Type:-CHINA. Chongqing Municipality, Beibei, Mt. Jinyun, Jinyun Mountain National Nature Reserve, $29^{\circ}$ 49' N, $106^{\circ} 20^{\prime}$ E, ca. 789 m alt., 10 July 2013, Bo Ding 20130701, with Qian Wang and Hai-Jun Wen (holotype, HAST; isotype, CDBI, E, IBSC, KUN, PE) 縉雲秋海棠.

\section{Diagnosis}

Begonia jinyunensis bears a superficial resemblance to $B$. hemsleyana in having palmately compound leaves, a feature unseen in other species of sect. Platycentrum in China. It is however sharply distinct from the latter in the acaulous habit with short aerial stems seen only at anthesis and long rhizomes (vs. erect stems to $70 \mathrm{~cm}$ or taller with short rhizomes), 4-6 pinnatilobed leaflets with indistinct, decurrent petiolules (vs. 7-10 serrate leaflets with distinct petiolules), and white (vs. pink) tepals.

\section{Description}

Herbs, monoecious; epipetric; perennial; rhizomatous. Rhizomes reddish-brown, $5-15 \mathrm{~cm}$ or longer, 6-16 mm across, subglabrous, internodes $2-12 \mathrm{~mm}$. Stipules reddishbrown, widely ovate, ca. 3-6×4-6 mm, slightly keeled, apex shortly aristate, subglabrous, deciduous. Leaves many,

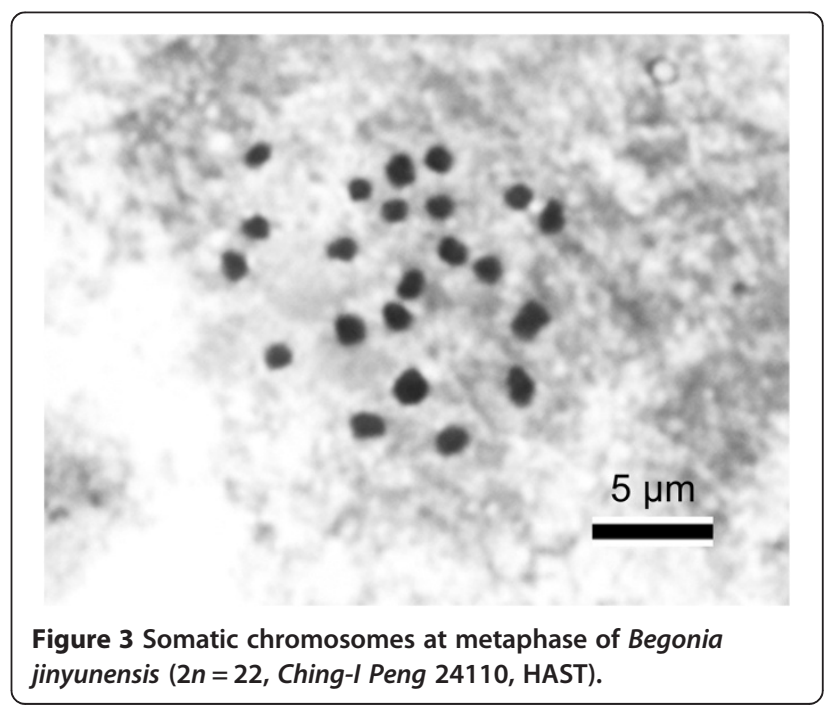




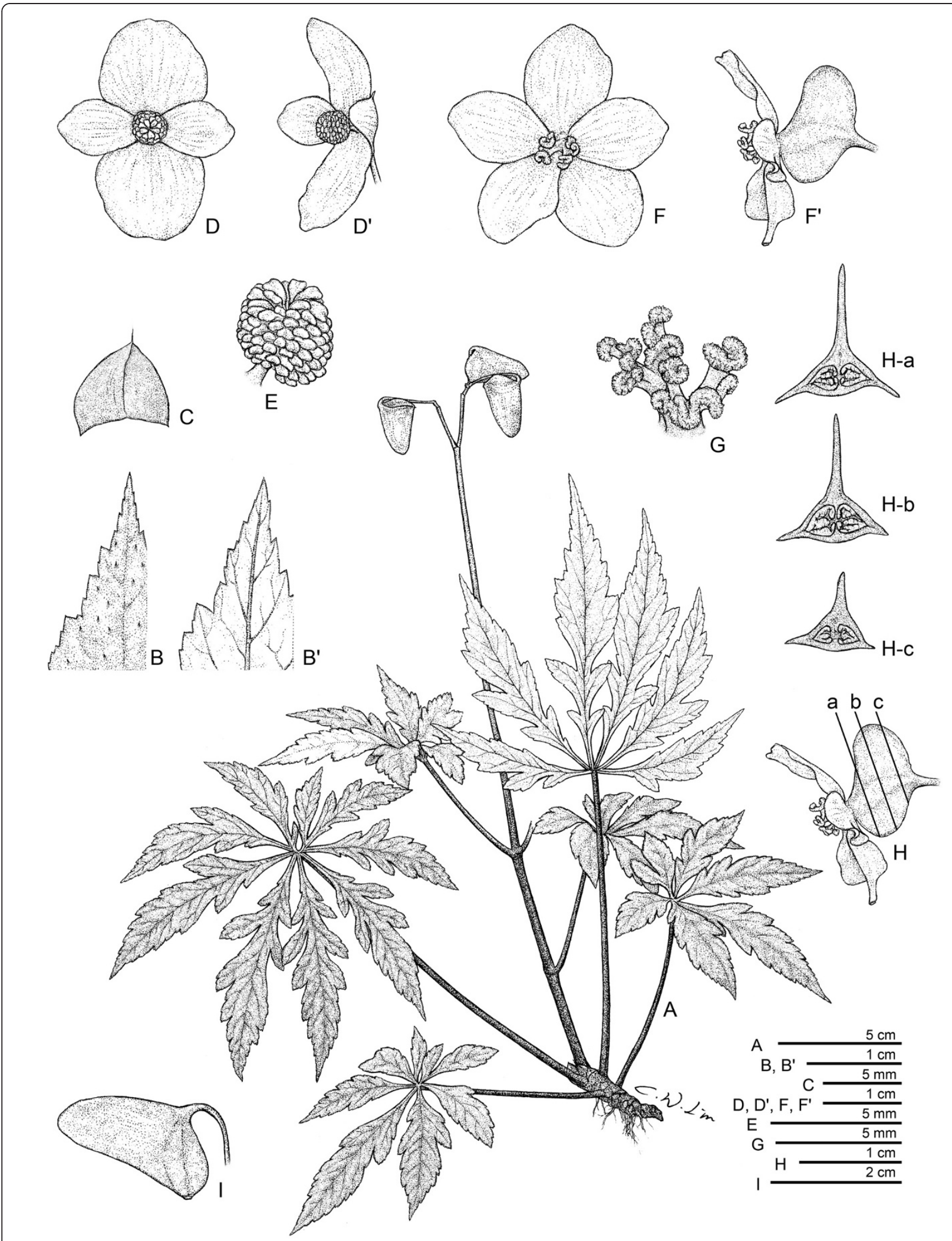

Figure 4 Begonia jinyunensis C.-I Peng, B. Ding \& Q. Wang. A, Habit; B, Leaf adaxial surface; B', Leaf abaxial surface; C, Stipule; D, Staminate flower, ventral view; D', Staminate flower, lateral view; E, Stamens; F, Pistillate flower, ventral view; F', Pistillate flower, lateral view; G, Styles and stigmas; H-a,b,c, Transverse sections of developing capsule; I, Capsule. [Drawn from Ching-l Peng 24108, 24109, 24110 (HAST)]. 


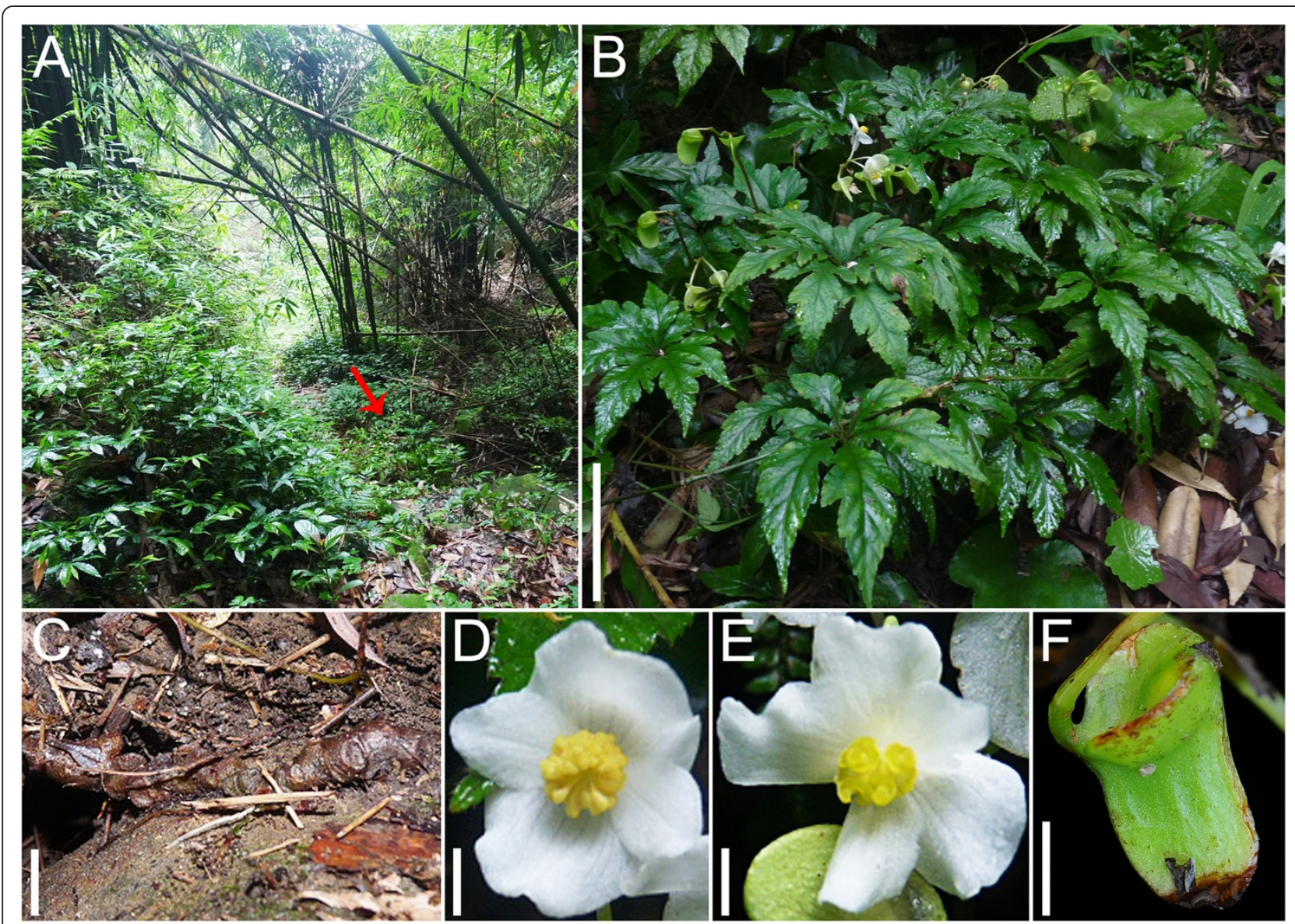

Figure 5 Begonia jinyunensis C.-I Peng, B. Ding \& Q. Wang. A, Habitat (B. jinyunensis indicated by an arrow); B, Habit; C, Rhizome; D, Staminate flower; E, Pistillate flower; $\mathbf{F}$, Capsule. Scale bars are $5 \mathrm{~cm}$ for $\mathbf{B}, 1 \mathrm{~cm}$ for $\mathbf{C}$ and $\mathbf{F}, 5 \mathrm{~mm}$ for $\mathbf{D}$ and $\mathbf{E}$. [A and $\mathbf{C}$ from Ching-l Peng 24109 (HAST); B, D, E, and $\mathbf{F}$ from Ching-l Peng 24108 (HAST)].

arising directly from the rhizome, with 1-3 cauline leaves at anthesis; petioles $10-22 \mathrm{~cm}$ long, subglabrous or sparely hispidulous. Blade pale to dark green above, tinged reddish (pronounced on veins) beneath, palmately compound, leaflets 4-6, obliquely oblong-lanceolate or obovatelanceolate, $4-10 \times 1.5-3 \mathrm{~cm}$, abaxially sparsely setulose, adaxially sparsely hirsute, margins pinnatilobed, apex caudate-acuminate or acuminate, base cuneate or attenuate into a short, winged petiolule $2-5 \mathrm{~mm}$ long. Inflorescence $10-35 \mathrm{~cm}$ long, subglabrous; pedicel $1-4 \mathrm{~cm}$; bracts ovate-oblong, $4-5 \times 2-3 \mathrm{~mm}$, apex acute. Staminate flowers: pedicel $11-15 \mathrm{~mm}$, tepals 4 , white, outer 2 broadly ovate, nearly as long as wide, $12-15 \times 11-15 \mathrm{~mm}$, inner 2 oblong-obovate, $8-10 \times 4-6 \mathrm{~mm}$; stamens numerous. Pistillate flowers: pedicel $10-40 \mathrm{~mm}$, tepals 5 , white, obovate to broadly obovate, 7-15 $\times 5-10 \mathrm{~mm}$; ovary 2loculed; placentae axile, bilamellate; styles 2, ca. $5 \mathrm{~mm}$ long, fused to halfway. Capsule nodding, ellipsiod, fruit body ca. $10-20 \mathrm{~mm}$ long, 7-12 $\mathrm{mm}$ thick (wings excluded), unequally 3-winged; abaxial wing falcate-ligulate,
12-18 mm wide. Somatic chromosome number, $2 n=22$ (Figure 3).

\section{Additional specimens examined}

CHINA. Chongqing Municipality. Mt. Jinyun, Pokong Tower, under shady rocks, $780 \mathrm{~m}$ alt., 5 August 1934, T.-H. Tu 5087 (IBSC); Mt. Jinyun ("Tsing-yun Shan"), s.d., received by IBSC in May 1940, L.-Y. Lin 1082 (IBSC); Mt. Jinyun, Jinyun Elementary School, collected and presented by Bo Ding, 29 July, 2013, Ching-I Peng 24108 (HAST); Mt. Jinyun, Qinglongzhai, collected and presented by Bo Ding, 29 July, 2013, Ching-I Peng 24109 (HAST); Mt. Jinyun, Shaolongguan, collected and presented by Bo Ding, 29 July, 2013, Ching-I Peng 24110 (HAST).

\section{Distribution, habitat and ecology}

Begonia jinyunensis is currently known only from Jinyun Mountain National Nature Reserve. The species usually grows on limestone faces of shaded moist 
environments such as valleys and broadleaved forests. Flowering in July; fruiting in August.

\section{Etymology}

The specific epithet is derived from the type locality, Mt. Jinyun.

\section{IUCN Red list category}

Vulnerable (VU D2). Begonia jinyunensis is known only from a narrow area of Mt. Jinyun, Chongqing Municipality. Although the area is under protection as a national nature reserve, habitat disturbance brought about by human activities such as tourism and maintenance/ building of roads/walking trails may have a negative impact on the species.

\section{Conclusions}

Detailed morphological observations and molecular phylogenetic analyses based on nuclear ribosomal DNA and chloroplast DNA sequences supported the recognition of the new species Begonia jinyunensis. Somatic chromosome number of $2 n=22$ was reported for this new species. Begonia jinyunensis is currently known only from the type locality, Mt. Jinyun, Chongqing Municipality, Southwest China.

\section{Appendix 1}

Begonia species included in the molecular phylogenetic analyses. Shown here are species name, section name (Diploclinium-DIP; Platycentrum-PLA; ReichenheimiaREI; Sphenanthera-SPH), voucher specimen (HAST), and GenBank accession numbers for rpl16 and ITS. Asterisks indicate samples sequenced in this study; sequences of the other samples were cited from Chung et al. (2014).

Begonia alveolata T. T. Yu, DIP, Ching-I Peng 20421, KF707933, AY048977. Begonia augustinei Hemsl., PLA, Ching-I Peng 20759, KF707936, KF636421. Begonia balansana Gagnep., SPH, Ching-I Peng 21928, KF707939, AF485091. Begonia cathayana Hemsl., PLA, Ching-I Peng 20288, KF707948, AF280106. Begonia decora Stapf, PLA, Ching-I Peng 20261, KF707956, KF636435. Begonia dryadis Irmsch., PLA, Ching-I Peng 18016, KF707959, KF636436. Begonia edulis H. Lév., PLA, Ching-I Peng 18747, KF707960, KF636437. Begonia handelii Irmsch., SPH, Ching-I Peng 17513, KF707969, AY048982. Begonia hatacoa Buch.-Ham. ex D. Don, PLA, Ching-I Peng 20861, KF707970, KF636444. Begonia hemsleyana Hook. f., PLA, Ching-I Peng 17590, KF707971, AF485099; Ching-I Peng 20204*, AB972933, AB972927; Ching-I Peng 20933*, AB972934, AB972928; Ching-I Peng 22778*, AB972935, AB972929. Begonia jinyunensis C.-I Peng, B. Ding \& Q. Wang, PLA, Ching-I Peng 24108*, AB972936, AB972930; Ching-I Peng 24109*, AB972937, AB972931; Ching-I Peng
24110*, AB972938, AB972932. Begonia laminariae Irmsch., PLA, Ching-I Peng 17447, KF707982, KF636455. Begonia longicarpa K. Y. Guan \& D. K. Tian, No section designation, Ching-I Peng 18651, KF707987, AY048985. Begonia longifolia Blume, SPH, Ching-I Peng 16795, KF707988, AF485105. Begonia oreodoxa Chun \& F. Chun ex G. Y. Wu \& T. C. Ku, PLA, Ching-I Peng 20454, KF707996, KF636467. Begonia palmata D. Don, PLA, Ching-I Peng 20993, KF707998, KF636468. Begonia parvula H. Lév. \& Vaniot, REI, Ching-I Peng 20396, KF708001, KF636471 Begonia pavonina Ridl., PLA, Ching-I Peng 20239, KF708002, KF636472. Begonia pedatifida H. Lév., PLA, Ching-I Peng 18779, KF708003, KF636473. Begonia ravenii C.-I Peng \& Y. K. Chen, DIP, Ching-I Peng 14855, KF708009, KF636479. Begonia ruboides C. M. Hu ex C. Y. Wu \& T. C. Ku, DIP, Ching-I Peng 18705, KF708011, KF636481. Begonia sikkimensis A. DC., PLA, Ching-I Peng 20848, KF708015, KF636485. Begonia taiwaniana Hayata, DIP, Ching-I Peng 18111, KF708020, KF636488. Begonia versicolor Irmsch., PLA, Ching-I Peng 18688, KF708023, AF485090. Begonia wenshanensis C. M. Hu ex C. Y. Wu \& T. C. Ku, DIP, Ching-I Peng 20516, KF708025, AY048974.

\section{Competing interests}

The authors declare that they have no competing interests.

\section{Authors' contributions}

Collection of the new species: BD. Morphological study: BD, KN, CIP. Molecular study: KN, MJH. Karyological study: KY. Draft preparation: KN, BD. Paper writing: KN, BD, YK, CIP. All authors read and approved the final manuscript.

\section{Acknowledgements}

We thank Qian Wang and Hai-Jun Wen for the help in field collection; the curator and staff of the herbarium IBSC for allowing us to study their specimens; Che-Wei Lin for the fine drawing, and our lab members in Academia Sinica for assistance in cultivation of plant materials in the experimental greenhouse. This study was supported in part by a series of research grants from National Science Council and Academia Sinica, Taiwan to CIP.

\section{Author details}

${ }^{1}$ College of Life Science and Engineering, Chongqing Three Gorges University, Chongqing 404000, China. ${ }^{2}$ Herbarium (HAST), Biodiversity Research Center, Academia Sinica, Taipei 11542, Taiwan.

Received: 30 June 2014 Accepted: 21 July 2014

Published: 2 August 2014

\section{References}

Chung K-F, Leong W-C, Rubite RR, Repin R, Kiew R, Liu Y, Peng C-I (2014) Phylogenetic analyses of Begonia sect. Coelocentrum and allied limestone species of China shed light on the evolution of Sino-Vietnamese karst flora. Bot Stud 55:1, doi:10.1186/1999-3110-55-1

Doorenbos JM, Sosef MS, de Wilde JJFE (1998) The sections of Begonia including descriptions, keys and species lists, Studies in Begoniaceae VI. Wageningen Agricultural University, Wageningen

Drummond AJ, Rambaut A (2007) BEAST: Bayesian evolutionary analysis by sampling trees. BMC Evol Biol 7:214, doi:10.1186/1471-2148-7-214

Felsenstein J (1985) Confidence limits on phylogenies: an approach using the bootstrap. Evolution 39:783-791

Gu C-Z (2007) Infrageneric classification of Begonia. In: Wu Z-Y, Raven P, Hong D-Y (eds) Flora of China, vol 13, Science Press. Beijing \& Missouri Botanical Garden Press, St. Louis, pp 205-207 
Gu C-Z, Peng C-I, Turland NJ (2007) Begoniaceae. In: Wu Z-Y, Raven P, Hong D-Y (eds) Flora of China, vol 13, Science Press. Beijing \& Missouri Botanical Garden Press, St. Louis, pp 153-207

Kiew R (2005) Begonias of Peninsular Malaysia. National History Publications (Borneo), Kota Kinabalu, Malaysia, and Singapore Botanic Gardens National Parks Board, Singapore

Ku S-M, Kono Y, Liu Y (2008) Begonia pengii (sect. Coelocentrum, Begoniaceae), a new species from limestone areas in Guangxi, China. Bot Stud 49:167-175

Levan A, Fredga K, Sandberg AA (1964) Nomenclature for centromeric position on chromosomes. Hereditas 52:201-220

Li H-Z, Ma H, Zhou Z-K, Guan K-Y (2008) A new species of Begonia (Begoniaceae) from Guangxi, China. Bot J Linn Soc 157:83-90

Liu Y, Ku S-M, Peng C-I (2007) Begonia bamaensis (sect. Coelocentrum, Begoniaceae), a new species from limestone areas in Guangxi, China. Bot Stud 48:465-473

Nakamura K, Chung K-F, Huang C-J, Kono Y, Kokubugata G, Peng C-I (2012) Extreme habitats that emerged in the Pleistocene triggered divergence of weedy Youngia (Asteraceae) in Taiwan. Mol Phylo Evol 63:486-499

Nakata M, Guan K-Y, Godo T, Lu Y-X, Li J-X (2003) Cytological studies on Chinese Begonia (Begoniaceae) I. Chromosome numbers of 17 taxa of Begonia collected in 2001 field studies in Yunnan. Bull Bot Gard Toyama 8:1-16

Peng C-I, Liu Y, Ku S-M (2008a) Begonia aurantiflora (sect. Coelocentrum, Begoniaceae), a new species from limestone areas in Guangxi, China. Bot Stud 49:83-92

Peng C-I, Ku S-M, Kono Y, Chung K-F, Liu Y (2008b) Two new species of Begonia (sect. Coelocentrum, Begoniaceae) from limestone areas in Guangxi, China: B. arachnoidea and B. subcoriacea. Bot Stud 49:405-418

Peng C-I, Liu Y, Kono Y (2010) Begonia X breviscapa (Begoniaceae), a new intersectional natural hybrid from limestone areas in Guangxi, China. Bot Stud 51:107-117

Peng C-I, Ku S-M, Kono Y, Liu Y (2012) Begonia chongzuoensis (sect. Coelocentrum, Begoniaceae), a new calciphile from Guangxi, China. Bot Stud 53:283-290

Peng C-I, Yang H-A, Kono Y, Chung K-F, Huang Y-S, Wu W-H, Liu Y (2013) Novelties in Begonia sect. Coelocentrum: B. longgangensis and B. ferox from limestone areas in Guangxi, China. Bot Stud 54:44, doi:10.1186/1999-31 10-54-44

Peng C-I, Wang H, Kono Y, Yang H-A (2014) Begonia wui-senioris (sect. Platycentrum, Begoniaceae), a new species from Myanmar. Bot Stud 55:13, doi:10.1186/19993110-55-13

Qing L, Li Y-X, Zhong Z-C (2004) Effects of moisture availability on clonal growth in bamboo Pleioblastus maculata. Plant Ecol 173:107-113

Ronquist F, Huelsenbeck JP (2003) MrBayes 3: Bayesian phylogenetic inference under mixed models. Bioinformatics 19:1572-1574

Shui Y-M (2007) Begonia tetralobata (Begoniaceae), a new species from China. Ann Bot Fenn 44:76-79

Shui Y-M, Peng C-I, Wu C-Y (2002) Synopsis of the Chinese species of Begonia (Begoniaceae), with a reappraisal of sectional delimitation. Bot Bull Acad Sin 43:313-327

Swofford DL (2002) PAUP: phylogenetic analysis using parsimony, version 4.0b10. Sinauer Associates, Sunderland

Tanabe AS (2011) Kakusan4 and Aminosan: two programs for comparing nonpartitioned, proportional and separate models for combined molecular phylogenetic analyses of multilocus sequence data. Mol Ecol Resour 11:914-921

Tebbitt MC (2005) Begonia: cultivation, identification, and natural history. Timber Press, Portland

Thomas DC, Hughes M, Phutthai T, Rajbhandary S, Rubite R, Ardi WH, Richardson JE (2011) A non-coding plastid DNA phylogeny of Asian Begonia (Begoniaceae): Evidence for morphological homoplasy and sectional polyphyly. Mol Phyl Evol 60:428-444

Thompson JD, Gibson TJ, Plewniak F, Jeanmougin F, Higgins DG (1997) The ClustalX windows interface: flexible strategies for multiple sequence alignment aided by quality analysis tools. Nucleic Acids Res 24:4876-4882

Tian D-K, Guan K-Y, Zhou Q-X, Gu Z-J (2002) Chromosome numbers of eight taxa of Begonia from Yunnan. Acta Bot Yunn 24:245-249

Wei Z-D, Shui Y-M, Zhang M-D, Zhang R-M (2007) Begonia coelocentroides YM Shui \& ZD Wei, a New Species of Begoniaceae from Yunnan, China. Acta Phytotax Sin 45:86-89

doi:10.1186/s40529-014-0062-6

Cite this article as: Ding et al:: Begonia jinyunensis (Begoniaceae, section Platycentrum), a new palmately compound leaved species from Chongqing, China. Botanical Studies 2014 55:62.

\section{Submit your manuscript to a SpringerOpen ${ }^{\odot}$ journal and benefit from:}

- Convenient online submission

- Rigorous peer review

- Immediate publication on acceptance

- Open access: articles freely available online

- High visibility within the field

- Retaining the copyright to your article

Submit your next manuscript at $\gg$ springeropen.com 